\title{
Sublacustrine channel-levee system of the Caruaçu member, southwest Recôncavo Basin, Bahia, Brazil
}

\author{
Lisie Carvalho Falcão ${ }^{1 *}$, Jorge Carlos Della Favera ${ }^{1}$
}

\begin{abstract}
Caruaçu Member (Maracangalha Formation) is an oil and gas producer in Recôncavo Basin, Brazil. This unit crops out in the coast of Todos os Santos Bay, near the Aratu Navy Base, in the Great Salvador, and in the Bom Despacho Ferry Station in the Itaparica Island. Caruaçu shows channel-fill and proximal levee facies in the first locality and sheet sands in the latter. In the southwest of the Cassarongongo and Taquipe fields area, these sandstones can be recognized in logs and have characteristic reflections in seismic lines. The channel cut is represented by white (negative polarity) reflections and channel filling is marked by black (positive polarity) reflections, which onlap the white ones. Levees are marked by elevations in the channel borders, which are channels flowed down the slope of the Maracangalha deltaic complex and sporadically formed crevasse-splay deposits. In the southeast Recôncavo, channels flowed into a large splay area, whose sheet sands coalesced laterally and vertically into thick sand bodies. Caruaçu sandstones form unconventional oil and gas traps as they frequently do not present oil or gas/water contact. In the deepest part of the basin, they behave as tight-gas sands.
\end{abstract}

Keywords: Recôncavo Basin; system of channel-levees; Caruaçu Member; Maracangalha Formation; oil and gas exploration.

Resumo Sistemas de canais-diques marginais do membro Caruaçu, Bacia do Recôncavo, Sudoeste da Bahia, Brasil. O Membro Caruaçu da Formação Maracangalha produz óleo e gás na Bacia do Recôncavo, Bahia, Brasil. Esta unidade aflora na costa da Baía de Todos os Santos, próximo à Base Naval de Aratu, na Grande Salvador e na estação de ferryboat em Bom Despacho, Ilha de Itaparica. Os arenitos Caruaçu apresentam fácies de preenchimento de canal e de diques marginais proximais, na primeira localidade, e areias em lençol na última. Na área a Sudoeste dos campos de Cassarongongo e Taquipe, estes arenitos podem ser reconhecidos em perfis de poço além de apresentarem reflexões características em linhas sísmicas. O corte dos canais é marcado por reflexões de pico branco (polaridade negativa), enquanto que o preenchimento é marcado por reflexões do negro (polaridade positiva), as quais sobrepõem as primeiras. Os diques marginais são marcados por elevações nas bordas dos canais, que fluem por meio do talude do complexo deltaico Maracangalha e esporadicamente formam depósitos de crevasse-splay. A Sudeste da bacia, os canais fluíam para uma ampla área de espraiamento, cujos arenitos em lençol coalescem vertical e lateralmente em espessos corpos de areia. Os arenitos Caruaçu formam trapas para petróleo e gás não convencionais, pois frequentemente deixam de apresentar contatos dos hidrocarbonetos com a água. Nas partes mais profundas da bacia, comportam-se como arenitos fechados com gás.

Palavras-chave: Bacia do Recôncavo; sistema de canais e diques marginais; membro Caruaçu; Formação Maracangalha; exploração de petróleo e gás.

INTRODUCTION The Recôncavo Basin is a prolific rift basin in a mature stage of exploration. It is part of an aborted rift and has a stratigraphic succession developing since the Permian, passing by the late Jurassic up, and ending in the Early Cretaceous (Fig. 1). After a pre-rift phase, represented by the Afligidos, Aliança, Sergi, Itaparica, and Água Grande formations, mostly before the Early Cretaceous, the rift was installed and the Candeias, Maracangalha, Marfim, Pojuca and São Sebastião formations were deposited. The Candeias Formation resulted from deposition in a fresh deep-water lake. Soon after and in an unconformable way, the Maracangalha and Marfim deltaic complex was installed. Deposition in rift ended in a shallow river-dominated delta to alluvial plain setting. Before the Aptian, the basin was submitted to a post-rift tectonic phase, which produced local inversions.

The correlation of the Recôncavo Basin with other worldwide basins has been more difficult due to its continental nature, and consequent lack of index fossils. Local stratigraphy is based on ostracod biozonation, which has a very good performance in high-resolution stratigraphy.

The tectonic framework is displayed in Fig. 2. The Mata-Catu transference fault divides the basin into the Northern part (represented by the Northeast and central compartments), and the Southern one. The faulted margin of the basin is the SalvadorFault System in the East. The main source areas were 
situated in the Western flexural margin and the sediment flow was mostly axial.

The deep-water character of the Recôncavo was recognized in the early seventies by Klein et al. (1972), who described the water-escape structures found in several units and proposed a depositional system that joined shallow - and deep-lake facies, as a delta complex. Their goal was to understand the relationship between massive sands (the Pitanga Member) and less-deformed sandstones (Caruaçu Member).

In the last years, the Starfish Oil \& Gas S.A. has been working in the Recôncavo Basin and has faced the issue of the Caruaçu Member. The issue is that this unit behaves as a nonconventional reservoir in most cases. It shows a channel-like shape in seismic lines, and normally their tight sandstones do not present hydrocarbon-water contacts. The outcrops that were studied revealed important features to solve this problem.

\section{OUTCROPS NEAR THE ARATU NAVY BASE}

The coast near the Wanderley de Pinho Museum at the Caboto Village presents well-preserved outcrops of the Caruaçu Member. Two facies groups characterize the depositional setting. The first is interpreted as the channel fill, which is highly discontinuous, with fine to medium sandstones, in part with large dipping eastward foresets, some water escape structures, like convolute bedding, and autoclastic breccias (Fig. 3).

Such brecciation can be caused by two reasons: slump from the channel margins and simple water escape. It normally covers the main channel fill and presents admixtures of sandstones and shales by continuous pull-apart. Shales represent overbank contribution. The stress pillars (Fig. 4) are formed by sand squeezing during water escape. They are locally present as well as escape chimneys in sand volcanoes (Fig. 5). This sedimentary arrangement with a central chimney and lateral curvatures of flow lines is a common feature in outcrops of Caruaçu and Pitanga members. Large claystone balls, with $1 \mathrm{~m}$ diameter, are immersed into the sandstones, allowing the development of alveolar structures generated by erosion. Shale cominuition, which is formed by continuous shale pull-apart during water escape, makes a secondary clay matrix in the sandstones. The evolution of this process, towards an extreme homogenization, characterizes the Pitanga Member, widespread within the basin.

On the other hand, in the channel margin, there is the proximal levee facies, made of fine to very fine

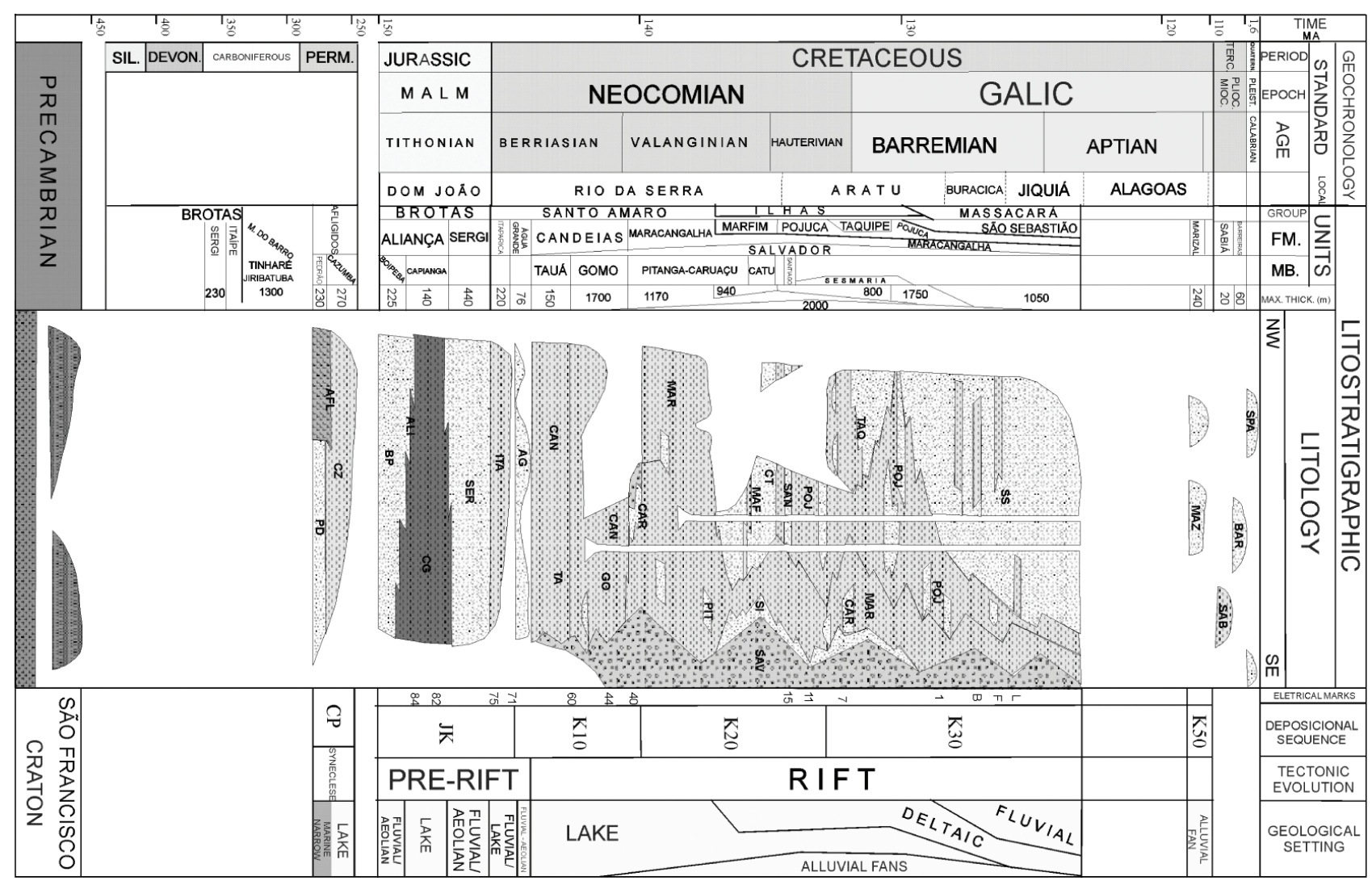

Figure 1 - Recôncavo Basin stratigraphic chart, which summarizes the Recôncavo stratigraphy and was prepared by Caixeta (1993) and has been distributed by the National Agency on Petroleum (ANP). 


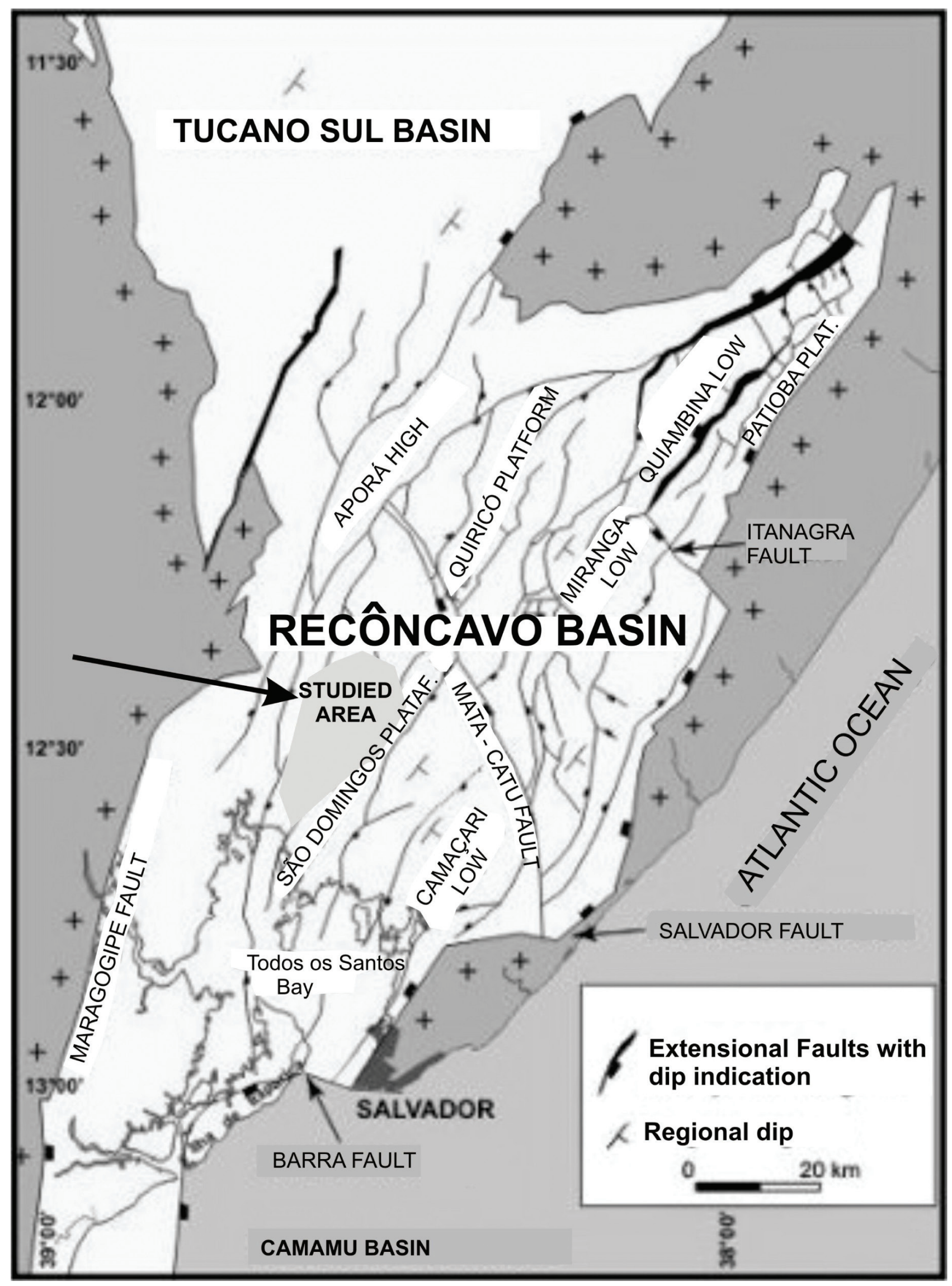

Figure 2 - Recôncavo Basin tectonic framework, prepared in the eighties. It has been distributed by ANP, with no authorship. 
sandstones entirely with climbing ripples. In the lower position, fine to silt-laminated sandstones present sets of hummocky cross stratification (HCS), $1 \mathrm{~m}$ in crest spacing. Differently from the channel fill facies, it is quite undeformed (Fig. 6). Here, it is associated with HCS, interpreted by Mutti et al. (1996) as a product of catastrophic floods on deltas. The bidirectional movement of sands, responsible for the HCS, would be a product of current wandering in the channel sides.

\section{OUTCROPS IN THE BOM DESPACHO FERRY STATION, ITAPARICA ISLAND In the North} of Bom Despacho Ferryboat Station, there is an excellent outcrop of turbidite sandstones, which characterizes successive depositional lobes. It presents a plane-bed arrangement, in coarsening and thickening upwards cycles and contains the Mutti (1992) F5, F8, and F9 facies. Some beds present the ball-and-pillow structures. Climbing ripples and some sole marks depict

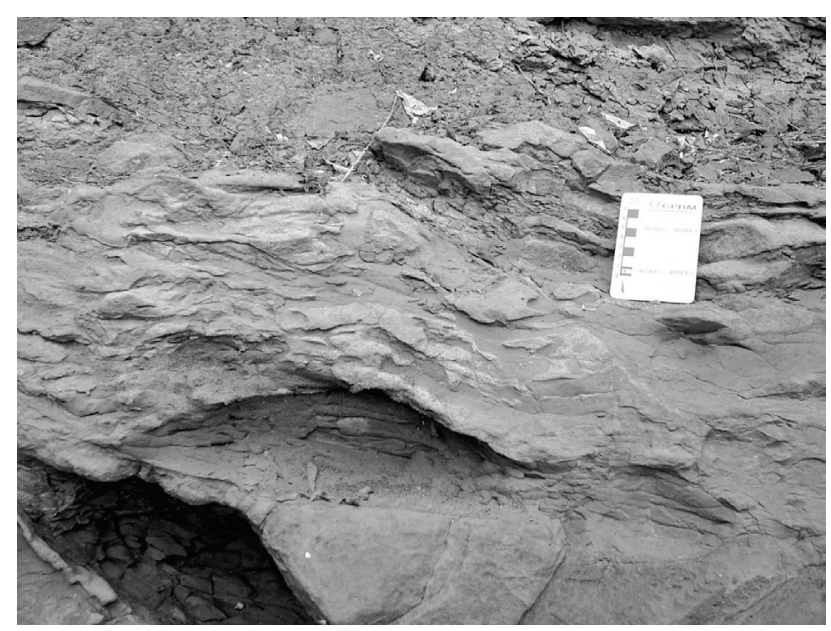

Figure 3-Channel fill. Autoclastic breccia.Wanderley de Pinho Museum, Caboto, Bahia, Brazil.

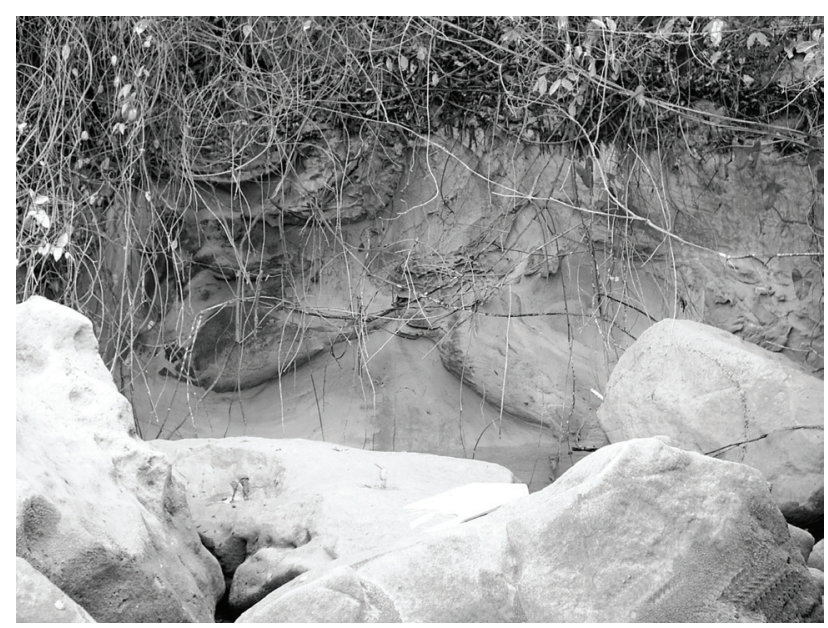

Figure 5 - Channel fill. Sand volcano. Wanderley de Pinho Museum, Caboto, Bahia, Brazil. an Eastern sediment source. The sandstone continuity is only apparent, since there is a thickness compensation, i.e., bed thins laterally towards the thicker part of another, making a false continuity (Fig. 7). Sandstones grade laterally and upwards to shale. An interesting fact in this outcrop is the presence of hemipelagites, represented by thin coal laminae, in the thin-laminated facies. Hemipelagites are abundant separating distal fine-laminated turbidites in the base of cycles.

\section{CHANNEL-LEVEE SYSTEM INDICATED BY LOGS AND SEISMIC LINES IN THE SOUTHWEST RECÔNCAVO G a m m a -} ray $\operatorname{logs}$ from Starfish wells in the Southwestern margin of the Cassarongongo and Taquipe fields depict fining upwards trends, which suggest

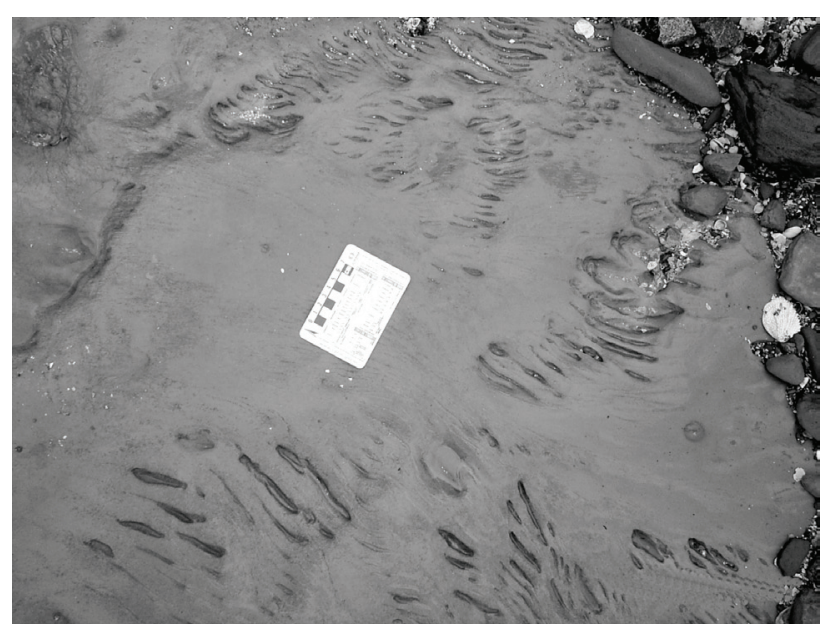

Figure 4 - Channel fill. Stress pillars in plane view. Wanderley de Pinho Museum, Caboto, Bahia, Brazil.

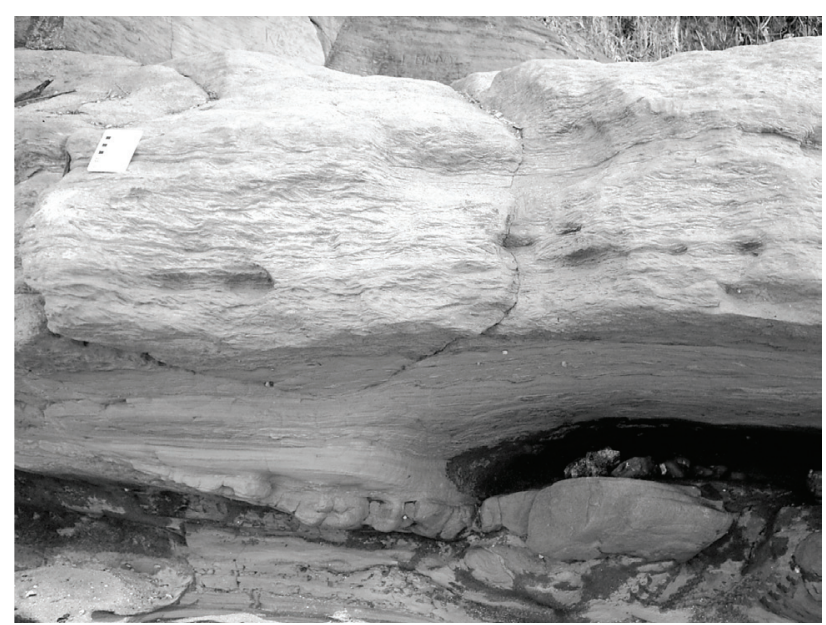

Figure 6 - Proximal levee. Successive trains of climbing ripples mark the outcrop depicting two opposite directions of sand transportation, East and Westward. Wanderley de Pinho Museum, Caboto, Bahia, Brazil. 
channel filling and later abandonment. In good quality 3D-PSDM (pre-stack depth migration) seismic lines, these sandstones present channelized forms, where the channel cut and its filling are recognized, respectively, through white negative and black positive peak reflections (Fig. 8). White peak (negative polarity) reflections would mean the channel cut, whereas the black ones (positive polarity) would represent the filling. A channel like this can be followed throughout the 3D volume, and its plane-view expression can be seen in a slice or a horizon map, which configure a meandering channel and its levees (Fig. 9). Mapping of seismic attributes, such as amplitude, reveals also a similar meandering pattern.

These meandering channels were interpreted as sublacustrine, due to their position with respect to basin evolution. They are below the Marfim Formation, representing the shallow portion of the deltaic complex, and above the Candeias shales, considered as deposited in a deep basinal setting. In essence, they are very similar to submarine channels

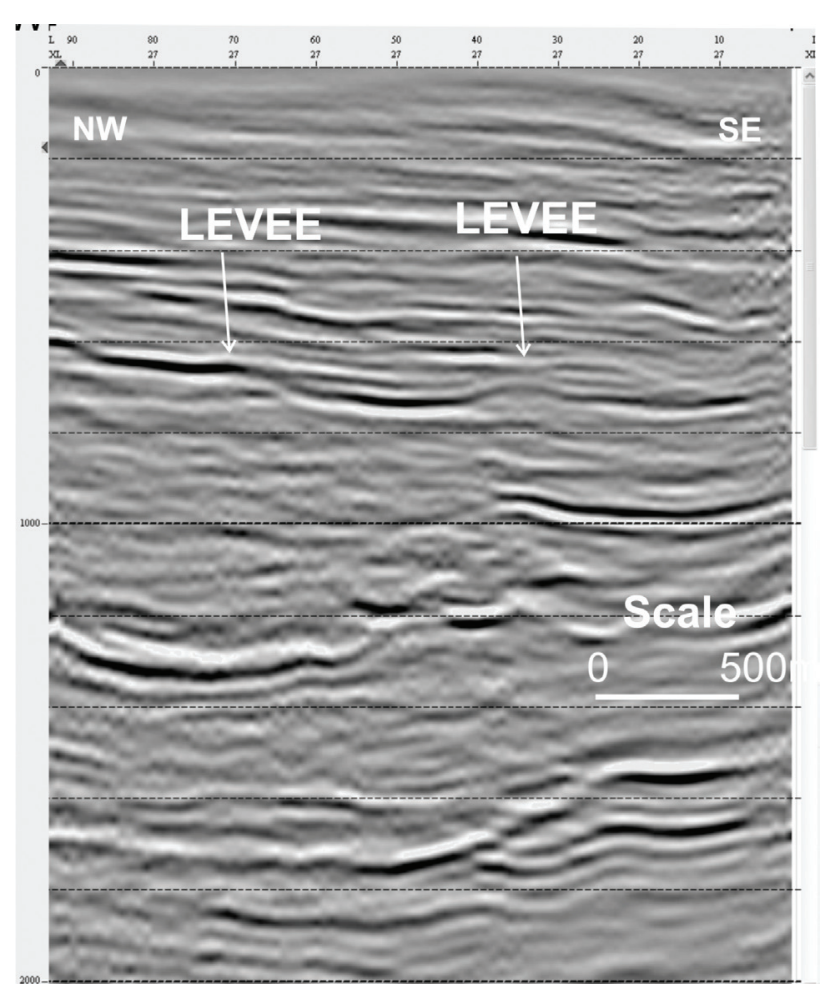

Figure 8-3D seismic section shot in the studied area depicting a channel-levee system in the Caruaçu Member. Note the black peak reflection (channel fill) onlapping the white one. The white reflection is considered the base of channel, whereas the black one (positive polarity) represents the channel filling. At this scale, the internal discontinuity in the channel cannot be perceived. as those depicted by Slatt (2002) in the Lewis Shale of the Green River Basin, Wyoming, USA (Fig. 10).

\section{SEDIMENTARY FAIRWAYS AND CHANNEL \\ TRACES Situated near the flexural basin mar-} gin, the studied area had been a preferred fairway to basin filling. A major depositional feature in this area is the Taquipe Canyon (Amorim 1992), which was one of the last filling episodes in the Aratu Stage (Hauterivian-Barremian). The seismic lines in a 3D

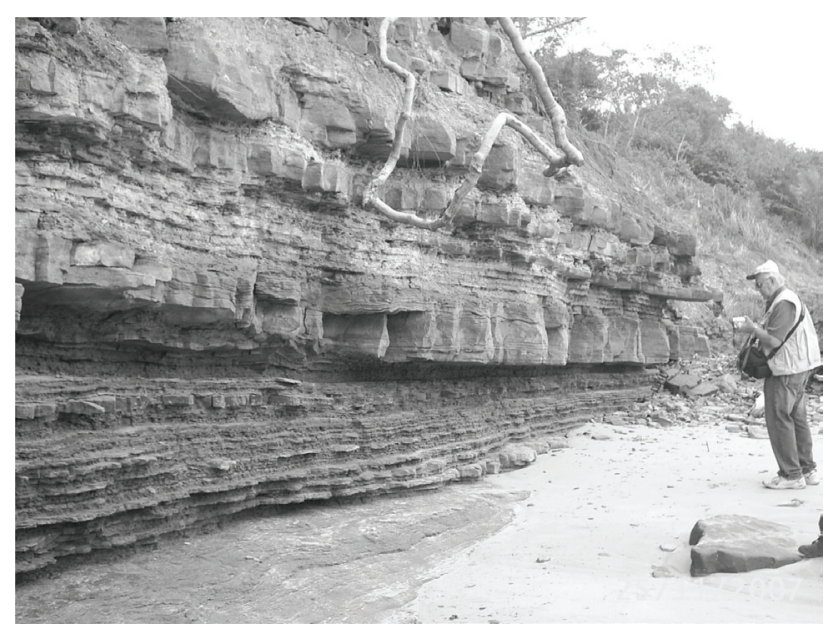

Figure 7 - Sheet sandstones with compensation thickness arrangement. These sands represent outflow deposition from channels as turbidite lobes. The photograph shows two coarsening and thickening upward cycles, beginning with $F 9$ facies and ending with F5 or F8 facies (Mutti, 1992). East of Bom Despacho Ferry Station, Itaparica Island.

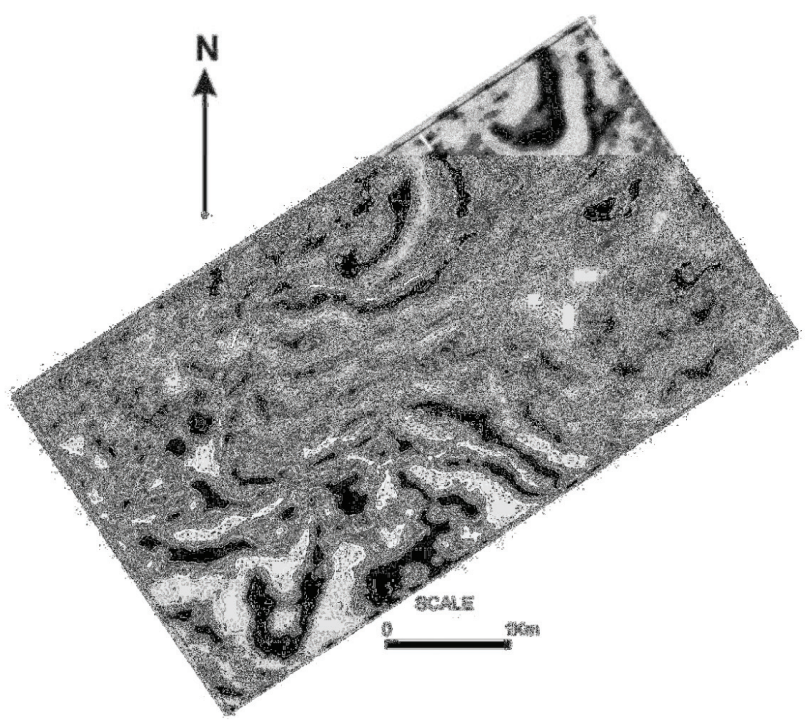

Figure 9 -Depth-slice map of a $3 D$ volume at $780 \mathrm{~m}$ in the studied area. A meander bend can be followed along black peak reflections, representing the channel fill. Scattered curved white reflections indicate other channels or even abandoned meanders. 
volume showed a great profusion of sublacustrine and fluvial channels starting from the Gomo Member up to surface. The channels follow tectonic and sedimentary pathways, like contemporary downthrown fault blocks and shale-diapir peripheral synclines. Therefore, the present model, applied to Caruaçu sandstones, can be used to other channel-levee systems found in the Taquipe Canyon.

One channel was correlated up to $12 \mathrm{~km}$ southwards, keeping the same log signature (Fig. 11) of the so-called Caruaçu " 1 " sandstone. If the gamma-ray curves of the wells in Fig. 11 are compared, one

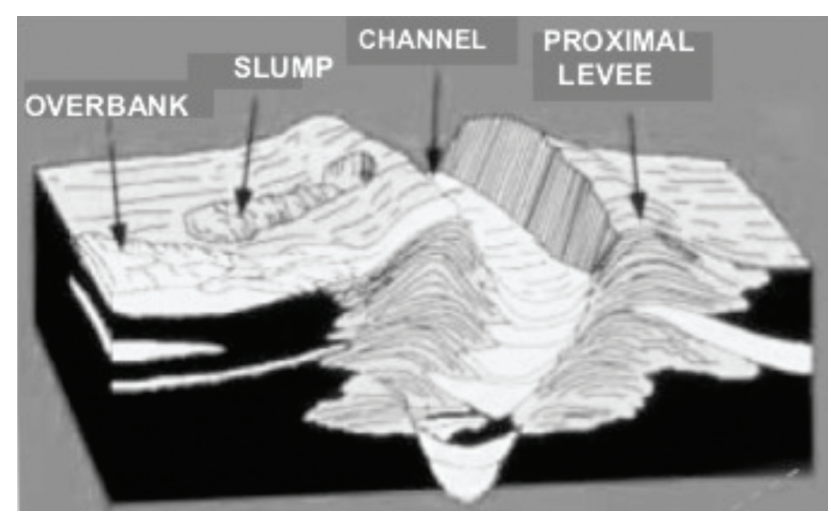

Figure 10 - Model for submarine meandering channel, applied to Caruaçu sandstones (Slatt, 2002). The Slatt presentation on the Internet clarifies the model for submarine channels and stresses the importance of studying outcrops as the best and the cheapest visualization way of a given depositional system. should note two sand bodies bearing a "bell" shape, which means a fining upward in grain size. This represents the lateral migration of the channel axis and afterwards a return to the former position. The sedimentary volume implied in this transport requires a catastrophic flood or seismicity, in order to establish a hyperpycnal flow large enough to reach such distal regions. On the other hand, Fig. 12 shows a gamma-ray log curve of a sheet sandstone of the same well. In this part of basin, this probably represents a sublacustrine crevasse-splay deposit.

Early deformation water-escape processes probably caused injectites (Huuse et al. 2007) to be formed in diapir flanks or in downthrown faulted blocks (Fig. 13). Injectites have been recognized as a new type of a prolific reservoir in some basins. They bear several common points with the Caruaçu Member, since they were described originally as submarine channels before fluidization and injection in the host rock.

Towards the Southeast part of the basin, the flow into channels produced turbidite splays that spread and coalesced through wide areas between diapirs.

\section{RELATIONSHIP OF CARUAÇU SANDSTONES TO THE PITANGA MASSIVE SANDSTONES}

The Pitanga Member is characterized by massive sandstones in a sort of depositional geometry. such as giant plugs (up to $1 \mathrm{~km}$ high), channels and fluidization forms (Falcão 2008). Its seismic velocity is around 3,600 m/seconds, which can produce seismic pull-ups in appropriate settings. The Pitanga Member

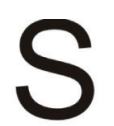

well «A»

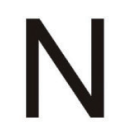

well «B»
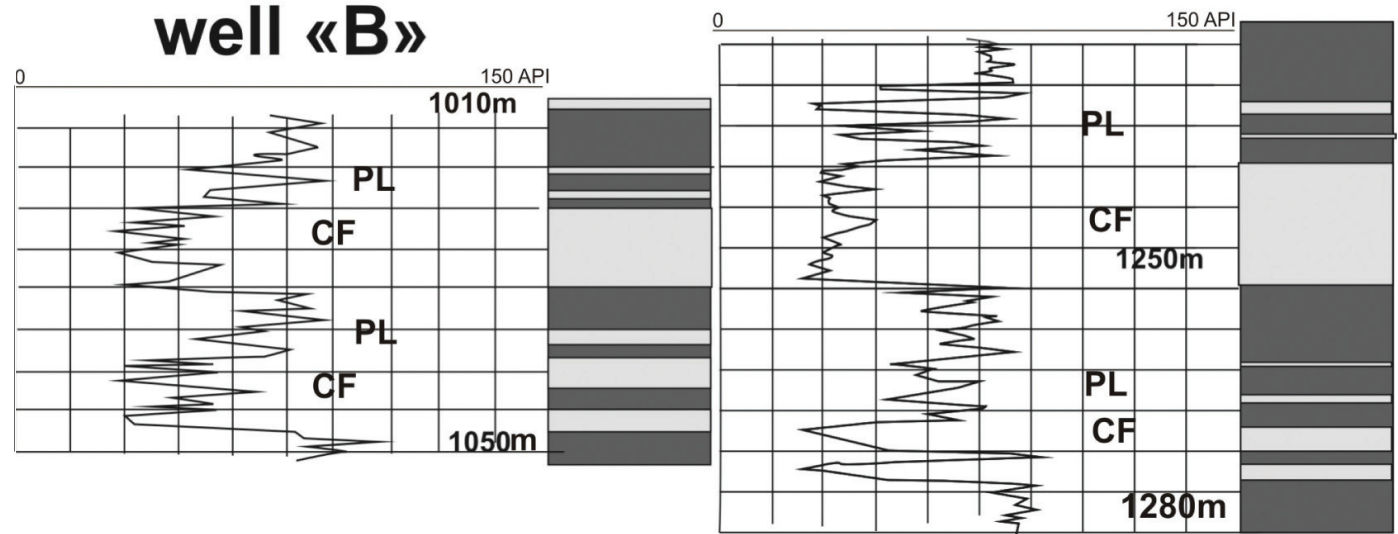

CF: channel fill; PL: proximal levee.

Figure 11 - Correlation of gamma-ray curves of Caruaçu sand "1" in two wells, $12 \mathrm{~km}$ apart. Two sand bodies, representing distinctive channels, have the same expression on logs. The "bell" shape of each sand body represents a fining upwards in grain size as a function of channel lateral migration; sharp base indicates erosion at the base of the channel. 
comprises mainly sandstones with a high matrix content, which can reach $50 \%$ in volume. According to Klein et al. (1972), the massive sandstones were generated by slurry flows that froze in delta front troughs. Later on, Della Favera (1984), examining sandstones at the diapir flanks, hypothesized that homogenization could be produced in situ, through seismic shocks, during diapir upheaval, or basin faulting. In outcrops, the Pitanga Member presents homogeneous sandstones with brain-like internal circumvolutions ("cerebroid facies", Fig. 14). Circumvolutions are the result of water escape upwards, similarly to sand volcanoes (Montenat et al. 1993). The addition of clay matrix is a process related to water escaping and it is done throughout a continuous pull-apart (cominuition) of shale clasts. Thus, the difference between Pitanga and Caruaçu members is the degree of homogenization, which is dependent on the scale of water escaping. An informal name for Caruaçu is "Pitangoid facies", which means a similar facies to Pitanga, but that is able to produce gas or even oil due to a lesser degree in homogenization.

\section{well «A»}

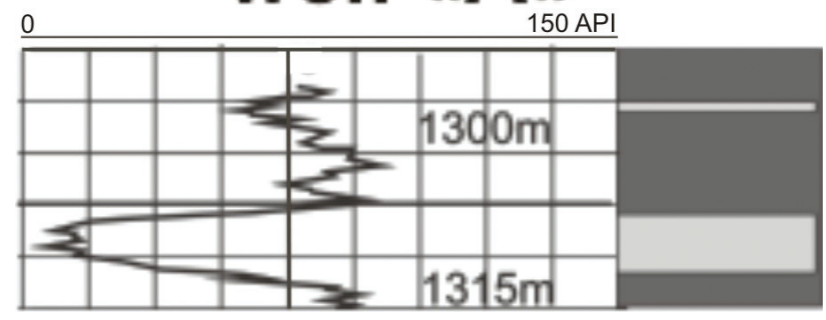

Figure 12 - Gamma-ray log of a sheet sand. This portion is below the channel-levee sandstones in the same well. Note the coarsening upwards arrangement of beds. Both sand bodies represent crevasse-splay deposits.

\section{PETROLEUM AND GAS EXPLORATION}

Caruaçu sandstones are considered nonconventional reservoirs for they are very low permeability sandstones, laterally discontinuous and frequently do not present water contacts. However, they may enclose a considerable volume of gas, which, despite the low recovery, could constitute an important source for the future, due to increased pricing and improved technology. An important concept to be raised here is the 'sweet spot', as used in tight sands exploration, which means a favorable area in a tight sand reservoir that presents a better porosity and permeability or even a more continuous geometry or to a higher degree in natural fracturing. There are some sweet spots in the Recôncavo Basin, such as the classic 3-MP-0003-BA

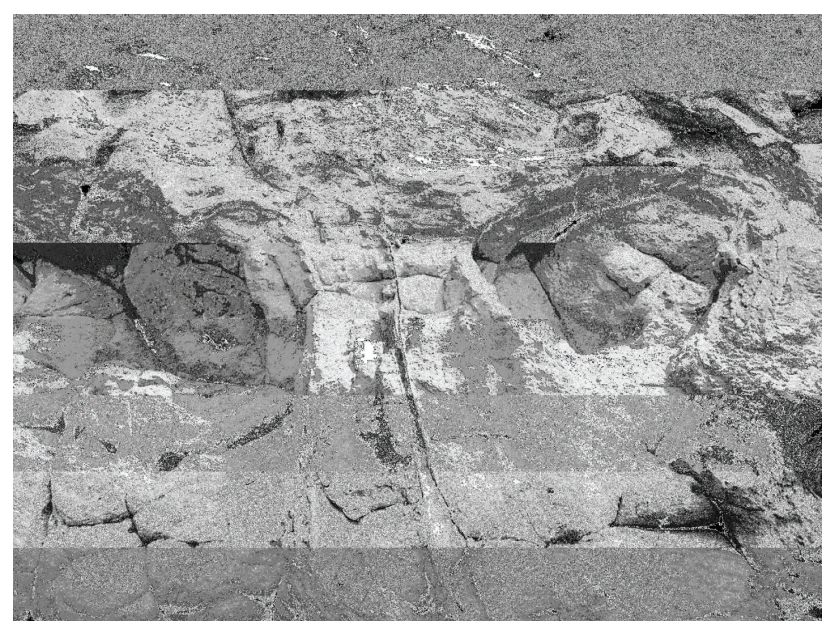

Figure 14 - Pitanga Member presenting "cerebroid" facies and sand volcano-like features. In the center of the photograph, there is a water-escape chimney that bends flow lines for both left and right sides, in a circumvolutionary way. The sandstone presents a large matrix content (around 50\%). Ferrolho locality, Madre de Deus, Bahia, Brazil.

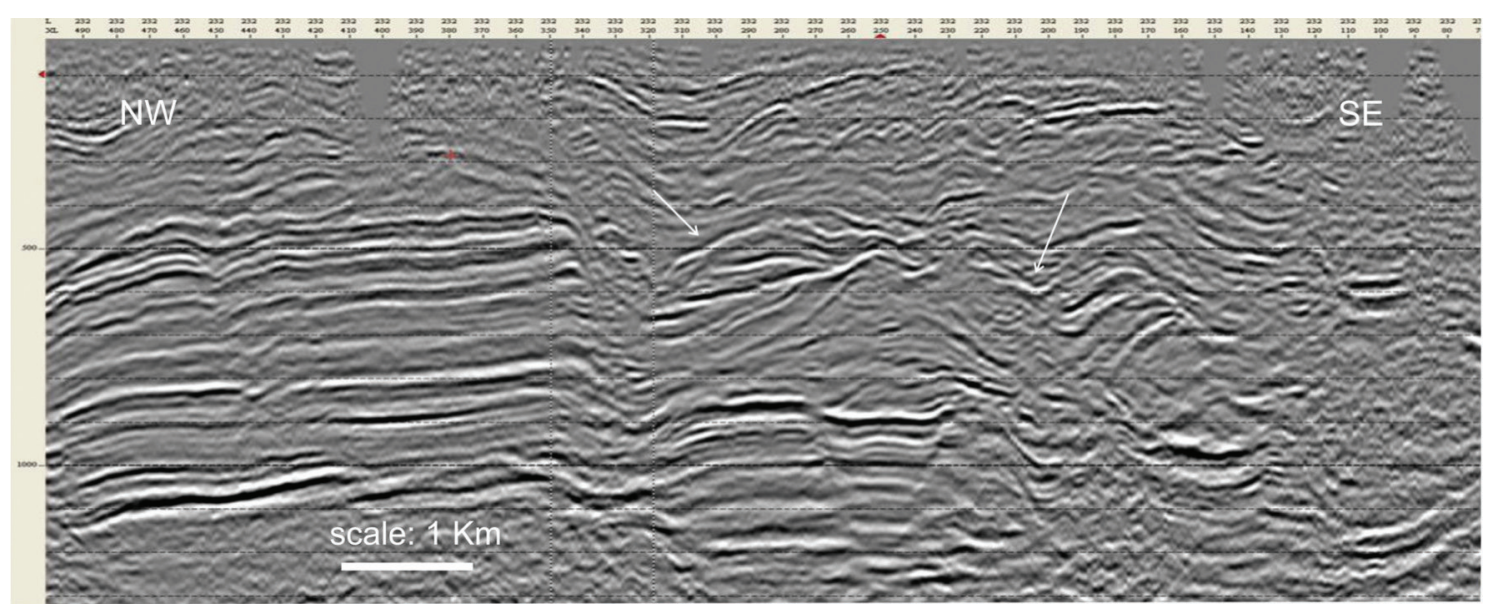

Figure 13 - 3D seismic line in South of studied area showing Caruaçu channels as injectites (wing-like reflections pointed out by arrows). 
well in the Massapê oil field. That well was unique in good reservoir characteristics, which were not found in the other wells drilled in the field.

Another point to be raised is the "basin-centered gas system" (Naik 2003), where the Caruaçu Member is involved. There are two depocenters in the Recôncavo Basin Central and Southern Compartments: the Miranga Low, in the Central, and the Camaçari Low, in the Southern one. Both are "kitchens" in terms of hydrocarbon generation. The
Miranga Profundo field (MGP) produces gas from the Caruaçu sandstones. Near the Southern compartment depocenter are the Rio Joanes, Lamarão and Cantagalo fields, which also produce gas from Caruaçu Member.

ACKNOWLEDGEMENTS Authors are indebted to doctor Kazumi Miura, Technical Director of Starfish Oil and Gas S.A., for releasing company data used in this paper.

\section{References}

Amorim J. 1992. Evolução do preenchimento do Cânion de Taquipe sob o enfoque da estratigrafia moderna. Dissertação de Mestrado, Universidade Federal do Rio Grande do Sul, Porto Alegre, 110 p.

Caixeta J.M., Bueno G.V., Magnavita L.P., Feijó F.J. 1994. Bacias do Recôncavo, Tucano e Jatobá. Boletim de Geociências da Petrobras, 8(1):163-172.

Della Favera J.C. 1984. Eventos de sedimentação episódica nas bacias brasileiras. Uma contribuição para atestar o caráter pontuado do registro sedimentar. In: SBG, XXXIII Congresso Brasileiro de Geologia, Anais, Rio de Janeiro, p. 489-501.

Falcão L. C. 2008. Investigação da natureza dos arenitos Pitanga, Bacia do Recôncavo. Monografia de Graduação, Universidade do Estado do Rio de Janeiro, Rio de Janeiro, 81 p.

Huuse M., Cartwright J., Hurst A., Steinsland N. 2007. Seismic characterization of large-scale sandstone intrusions In: Hurst A. \& Cartwright J. eds., Sand injectites: implications for hydrocarbon exploration and production. AAPG Memoir 87, p. 21-35.

Klein G., Mello U. \& Della Favera J.C. 1972. Subaqueous Gravity Processes on the front of Cretaceous Deltas,
Reconcavo Basin, Brazil. Geological Society of America Bulletin, 83:1469-1492.

Montenat C., Barrier P., d'Estevou P.O., Hibsch C. 1993. Seismites: An Attempt at Critical Analysis and Classification. Sedimentary Geology, 196:5-30.

Mutti E. 1992. Turbidite Sandstones. Milano, AGIP \& IGU, 275 p.

Mutti E., Davoli G., Tinterri R., Zavala C. 1996. The importance of ancient fluvio-deltaic systems dominated by catastrophic flooding in tectonically active basins. Estratto da Memorie di Scienze Geologiche, 48:233-291.

Naik C.K. 2003. Tight Gas Reservoirs - An Unconventional Natural Energy Source for the Future. Disponível em: www. sublette-se.org/files/tight gas.pdf. Accessado em: 01/07/2008.

Slatt R.M. 2002. Outcrop/Behind outcrop Characterization of Deepwater (Turbidite) Petroleum Reservoir Analogs: Why and How. AAPG, 2001-2002, Distinguished Lecture. Accessado em: 13/05/2008. Disponível em: http://www.aapg.org/education/dist lect/slides/2001_02/slatt.pdf.

Manuscrito ID 11914

Recebido em: 29/07/2008

Aprovado em: 23/04/2012 